\title{
The effects of anti-hypertensive drugs and the mechanism of hypertension in vascular smooth muscle cell-specific ATP2B1 knockout mice
}

\author{
Yuki Okuyama $^{1}$, Nobuhito Hirawa ${ }^{2}$, Megumi Fujita $^{1}$, Akira Fujiwara ${ }^{2}$, Yosuke Ehara ${ }^{1}$, Keisuke Yatsu ${ }^{1}$, \\ Koichiro Sumida $^{1}$, Minako Kagimoto ${ }^{1}$, Mari Katsumata ${ }^{2}$, Yusuke Kobayashi ${ }^{1}$, Sanae Saka ${ }^{2}$, Satoshi Umemura ${ }^{1}$ \\ and Kouichi Tamura ${ }^{1}$
}

\begin{abstract}
$A T P 2 B 1$ is a gene associated with hypertension. We reported previously that mice lacking $A T P 2 B 1$ in vascular smooth muscle cells (VSMC ATP2B1 KO mice) exhibited high blood pressure and increased intracellular calcium concentration. The present study was designed to investigate whether lack of the ATP2B1 gene causes a higher response to calcium channel blockers (CCBs) than to other types of anti-hypertensive drugs. Both VSMC ATP2B1 KO and control mice were administered antihypertensive drugs while monitoring blood pressure shifts. We also examined the association of nitric oxide synthase (NOS) activity in those mice to investigate whether another mechanism of hypertension existed. VSMC ATP2B1 KO mice exhibited significantly greater anti-hypertensive effects with a single injection of nicardipine, but the effects of an angiotensin II receptor blocker (ARB), an $\alpha$-blocker and amlodipine on blood pressure were all similar to control mice. However, long-term treatment with amlodipine, but not an ARB, significantly decreased the blood pressure of KO mice compared with control mice. Both mRNA and protein expression levels of the L-type calcium channel were significantly upregulated in KO VSMCs. There were no alterations in neural NOS protein expression of VSMCs or in urinary NO production between the two groups. VSMC ATP2B1 KO mice had a higher response to CCBs for blood pressure-lowering effects than other anti-hypertensive drugs. These results mean that increased intracellular calcium concentration in VSMCs due to lack of ATP2B1 and subsequent activation of L-type calcium channels mainly affects blood pressure and suggests increased susceptibility to CCBs in this type of hypertension.
\end{abstract} Hypertension Research (2018) 41, 80-87; doi:10.1038/hr.2017.92; published online 19 October 2017

Keywords: ATP2B1; calcium channel blocker; vascular smooth muscle cell

\section{INTRODUCTION}

Many studies have proven that $A T P 2 B 1$, which encodes plasma membrane calcium ATPase (PMCA) 1, is one of the candidate genes for hypertension. PMCAs are ATP-driven, calmodulin-dependent pumps that contribute to the regulation of intracellular calcium levels by extruding calcium ions from the cells. ${ }^{1}$ In the Millennium Genome Project in Japan, ${ }^{2}$ we demonstrated that single-nucleotide polymorphisms (SNPs) located upstream of the ATP2B1 gene were significantly associated with hypertension. These SNPs have been replicated in individuals of European descent, ${ }^{3}$ Korean descent ${ }^{4}$ and worldwide. ${ }^{5}$ We showed that SNPs in the ATP2B1 gene caused phenotypic changes in human tissue. ATP2B1 mRNA expression in human umbilical artery smooth muscle cells was significantly lower in those with a risk allele for hypertension than in those having no risk allele. ${ }^{6}$ The results of the study suggested that the low expression of ATP2B1 was associated with elevated blood pressure. Therefore, we generated a conditional knockout mouse model of ATP2B1 in vascular smooth muscle cells (VSMCs), and we reported increased blood pressure, intracellular calcium concentration and vascular contractility in these mice. ${ }^{7,8}$

On the other hand, ATP2B4 mRNA expression was upregulated in VSMCs of $A T P 2 B 1 \mathrm{KO}$ mice. ${ }^{7}$ We considered this upregulation as compensation for the lack of $A T P 2 B 1$. Mice overexpressing human PMCA4 in arterial SMCs exhibited high blood pressure, and PMCA4 overexpression was associated with the regulation of arterial contractility through neuronal nitric oxide synthase (nNOS) activity. ${ }^{9}$ We previously reported that systemically heterozygous ATP2B1-null mice exhibited enhanced vasoconstriction and elevated blood pressure, and the phenotype was associated with impaired endothelial NOS (eNOS) activity. ${ }^{10}$ However, NOS activity in VSMC-specific ATP2B1 knockout mice remains unknown.

In considering the treatment strategy for the hypertension caused by the lack of the ATP2B1 gene, which results in decreased extrusion of

${ }^{1}$ Department of Medical Science and Cardiorenal Medicine, Yokohama City University Graduate School of Medicine, Yokohama, Japan and ${ }^{2}$ Department of Nephrology and Hypertension, Yokohama City University Medical Center, Yokohama, Japan

Correspondence: Dr N Hirawa, Department of Nephrology and Hypertension, Yokohama City University Medical Center, 45-7, Urafune-cho, Minamiku, Yokohama 232-0024, Japan.

E-mail: hirawa@yokohama-cu.ac.jp

Received 3 March 2017; revised 21 June 2017; accepted 27 July 2017; published online 19 October 2017 
calcium ions from VSMCs, we hypothesize that calcium channel blockers (CCBs) are specifically effective compared with other antihypertensive drugs. CCBs are the most frequently prescribed antihypertensive agents in Japan because of their established blood pressure-lowering efficacy and their ability to maintain blood pressure control. ${ }^{11}$ Although there are few reports on the association between anti-hypertensive drug response and $A T P 2 B 1$ gene expression, it is important that efficacious treatment for this type of hypertension is discussed. The present study was undertaken to investigate whether lack of the ATP2B1 gene would cause a higher response to CCBs than other types of anti-hypertensive drugs. We compared the efficacies of several anti-hypertensive drugs on blood pressure, examined the NOS expression to investigate whether another mechanism of hypertension existed, and demonstrated the importance of calcium channel blockade.

\section{METHODS}

\section{Animal care}

Animals were housed under a 12-h light-dark cycle at a temperature of $25^{\circ} \mathrm{C}$. Mice were fed a normal-salt diet $(0.3 \% \mathrm{NaCl})$ with free access to drinking water. The experiments were conducted under the guidelines for animal experiments set by the Animal Experiment Committee of Yokohama City University School of Medicine.

\section{Mice}

$A T P 2 B 1^{\text {loxP/loxP }}$ mice were generated as previously described. ${ }^{7}$ To target inactivation of the ATP2B1 gene to VSMCs, ATP2Bl ${ }^{\text {loxP/loxP }}$ mice were intercrossed with transgenic mice expressing Cre recombinase under control of the mouse transgelin (smooth muscle protein $22-\alpha$ ) promoter [B6.Cg-Tg (Tagln-Cre)1Her/J, stock No.017491, Jackson Laboratory, Sacramento, CA, USA.$^{12}$ We generated $A T P 2 B 1^{\text {loxP/loxP}} / S M 22$ Cre (VSMC ATP2B1 KO) mice, and $A T P 2 B 1^{\text {loxP/loxP }}$ littermates were used as control mice.

\section{Blood pressure measurement by tail-cuff method and radio telemetric method}

Systolic blood pressure was measured by the tail-cuff method (BP-monitor MK-2000; Muromachi Kikai Co., Tokyo, Japan). Furthermore, direct blood pressure measurement was performed by a radio telemetric method in which a blood pressure transducer (PA-C10; Data Sciences International, Primetech Corp., Tokyo, Japan) was inserted into the left carotid artery at the age of 12 weeks. Ten days after transplantation, each mouse was housed individually in a standard cage on a receiver under a 12-hour light-dark cycle. Direct blood pressure was recorded every 3 or $5 \mathrm{~min}$ by the Dataquest ART Gold Acquisition software (Data Sciences International, Primetech Corp., Tokyo, Japan), and the data were calculated as the average value per hour.

\section{Effects of anti-hypertensive drugs on blood pressure}

To survey the mechanism of hypertension in VSMC ATP2B1 KO mice, the L-type CCBs nicardipine $\left(1 \mathrm{mg} \mathrm{kg}^{-1}\right)$ and amlodipine $\left(5 \mathrm{mg} \mathrm{kg}^{-1}\right)$, the angiotensin II receptor blocker (ARB), candesartan $\left(10 \mathrm{mg} \mathrm{kg}^{-1}\right)$, the $\alpha 1$-antagonist, prazosin $\left(1 \mathrm{mg} \mathrm{kg}^{-1}\right),{ }^{13}$ or the NOS inhibitor N $\omega$-nitro-Larginine methyl ester (L-NAME, $30 \mathrm{mg} \mathrm{kg}^{-114}$ ) were administered intraperitoneally to 14- to 18-week-old mice. All administrations were done at $\sim$ 3:00 pm. The injection volume was $0.3 \mathrm{ml}$. Saline was injected as a vehicle, and we confirmed that each administration of these drugs had blood pressurelowering effects. The drugs were washed out by resting three days between each injection. Blood pressure and heart rate shifts were evaluated by telemetry measurements. Next, amlodipine $\left(5 \mathrm{mg} \mathrm{kg}^{-1}\right.$ per day) or candesartan $\left(0.5 \mathrm{mg} \mathrm{kg}^{-1}\right.$ per day $\left.{ }^{15}\right)$ was administered for 2 weeks through a subcutaneously implanted osmotic pump (Alzet Osmotic Pumps; Durect Corp, Cupertino, CA, USA), and blood pressure and heart rate were monitored by tail-cuff or telemetric method. As there are several reports that candesartan could decrease blood pressure sufficiently in very low doses (0.1$1 \mathrm{mg} \mathrm{kg}^{-1}$ day) when mice were administered candesartan by osmotic pumps, ${ }^{15-17}$ we decided to reduce the doses of candesartan compared with the single injection for the long-term administration study.

\section{Vascular smooth muscle cell culture}

The aorta was dissected out from the aortic arch to the abdominal aorta from 8 -week-old mice. VSMCs were prepared by the explant method and cultured in $10 \%$ fetal bovine serum-Dulbecco's modified Eagle's Medium as described previously. ${ }^{18}$ After the desired incubation period, cells were rinsed with phosphate-buffered saline and then lysed and sonicated.

\section{Real-time quantitative reverse transcription-PCR analysis}

Total RNA was extracted from aorta and cultured VSMCs with ISOGEN (Nippon Gene, Tokyo, Japan), and cDNA was synthesized using the SuperScript III First Strand System (Thermo Fisher Scientific, Waltham, MA, USA). Real-time quantitative reverse transcription-PCR (qRT-PCR) was performed by incubating the reverse transcription product with TaqMan PCR Master Mix and a designed TaqMan probe (Thermo Fisher Scientific, Waltham, MA, USA). RNA quantities were expressed relative to the $18 \mathrm{~S}$ mRNA control.

\section{Western blot analysis}

Western blot analysis was performed as described previously. ${ }^{10}$ Briefly, VSMCs extracts were used for electrophoresis, and membranes (Thermo Fisher Scientific, Waltham, MA, USA) were incubated with anti-Ca $\mathrm{V}_{\mathrm{v}} 1.2$ (Alomone Labs, Jerusalem, Israel), anti-nNOS antibody (Cell Signaling Technology, Danvers, MA, USA), or anti- $\beta$-actin antibody (Abcam, Cambridge, MA, USA) and subjected to enhanced chemiluminescence (EMD Millipore, Darmstadt, Germany). The images were analyzed quantitatively using a FUJI LAS3000 Image Analyzer (FUJI Film, Tokyo, Japan) to determine each protein level.

Evaluation of nitric oxide production by measuring nitrate/nitrite Measurement of combined urinary nitrite and nitrate (NOx) excretion is widely used as a marker of nitric oxide (NO) production. Urine samples were collected for $24 \mathrm{~h}$ with metabolic cages and were deproteinized by centrifugation with an Amicon Ultra-0.5 filter (EMD Millipore, Darmstadt, Germany). We colorimetrically measured urinary NOx excretion applying the Griess reaction (Griess Reagent Kit; Dojindo, Kumamoto, Japan). ${ }^{10}$

\section{Statistical analysis}

For statistical analysis of differences among groups, an unpaired Student's $t$-test or analysis of variance (ANOVA) followed by the Bonferroni correction was used. All quantitative data are expressed as the mean \pm s.e.m. Values of P less than 0.05 were considered significant.

\section{RESULTS}

Baseline characteristics of VSMC ATP2B1 KO mice and control mice

As we reported previously, ${ }^{7}$ the blood pressure of VSMC ATP2B1 KO mice was higher than that of control mice, but heart rate and body weight were not significantly different. Serum and urinary electrolytes, including calcium and phosphate, were not different either (Supplementary Table). Systolic blood pressure was higher in the dark period (as the active phase for mice) than in the light period in both control and knockout mice (Supplementary Figure).

\section{Single injection of anti-hypertensive drugs}

Figure 1 shows the delta systolic blood pressure (SBP) by a single injection of vasodilators. Blood pressure-lowering effects were significantly greater in VSMC ATP2B1 knockout mice when nicardipine, which has a short half-life, was injected (Figure 1a, $P<0.05$ ). On the other hand, no significant change was seen when mice were injected with an $\mathrm{ARB}$ or $\alpha 1$-adrenoceptor blocker (Figures $1 \mathrm{~b}$ and $\mathrm{c}$ ). We administered amlodipine to mice as a long-acting L-type $\mathrm{CCB}^{19}$ to 
a

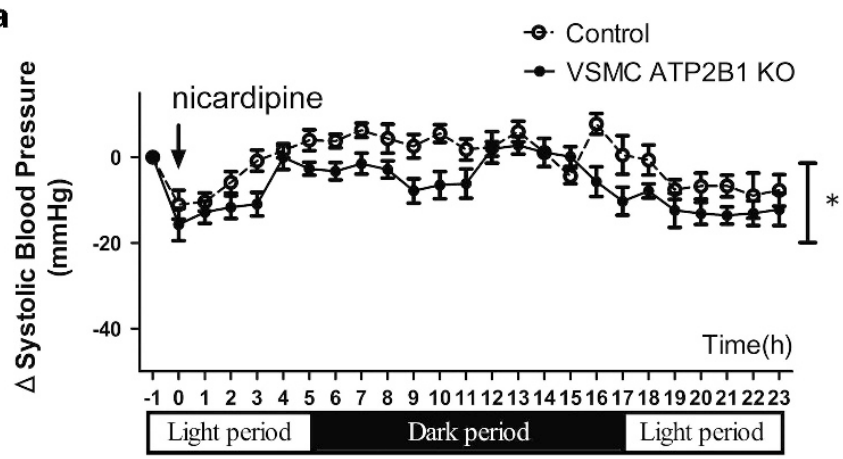

c

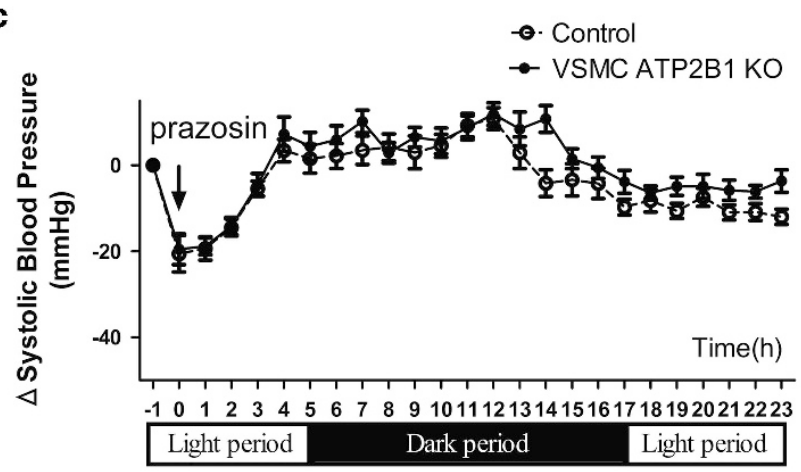

b

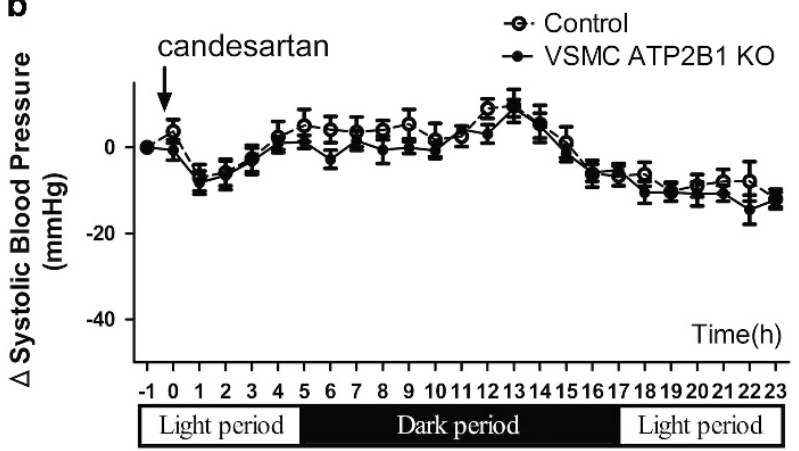

d

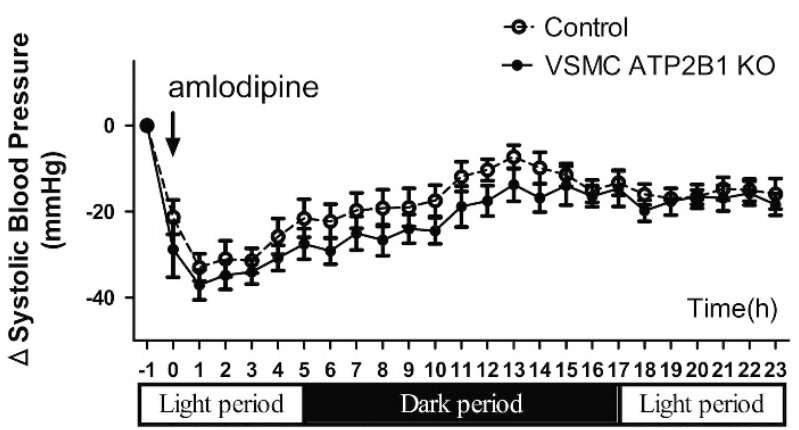

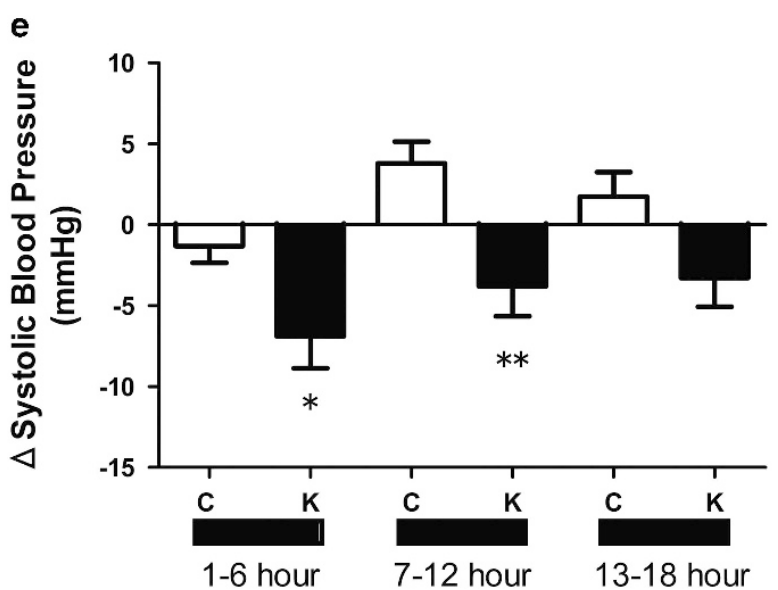

Figure 1 Changes in SBP produced by a single injection of anti-hypertensive drugs. (a) Delta SBP in response to the administration of nicardipine (1 $\mathrm{mg} \mathrm{kg}^{-1}$, i.p., $n=7$ for each group). (b) Delta SBP in response to the administration of candesartan (10 $\mathrm{mg} \mathrm{kg}^{-1}$, i.p., $n=8$ for each group). (c) Delta SBP in response to the administration of prazosin ( $1 \mathrm{mg} \mathrm{kg}^{-1}$, i.p., $n=6$ for each group). (d) Delta SBP in response to the administration of amlodipine ( $5 \mathrm{mg} \mathrm{kg}^{-1}$, i.p., $n=8$ for each group). (e) Delta SBP in response to the administration of nicardipine every $6 \mathrm{~h}$. The data are means \pm s.e.m. of each group. ${ }^{*} P<0.05$ vs. the control group. ${ }^{* *} P<0.01$ vs. the control group. Each arrow indicates the time of drug injection. A horizontal line shows the time after (or before) injection and each injection was at 15:00. C, control mice; K, VSMC ATP2B1 KO mice.

confirm the greater effects of a CCB on blood pressure in KO mice, but unexpectedly, SBP shifts were not significantly different (Figure 1d). Figure 1e shows the delta SBP for every $6 \mathrm{~h}$ after nicardipine injection, and greater anti-hypertensive effects were seen in VSMC ATP2B1 KO mice until $12 \mathrm{~h}$ after administration (1-6 h; $P<0.05,7-12$ h; $P<0.01)$.

Long-term administration of anti-hypertensive drugs Although the short half-life L-type CCB response could be evaluated by a single injection, we considered that long-term injection was needed for an amlodipine response because the drug has a long halflife. As shown in Figures 2a and b, SBP was significantly decreased by a 2-week-treatment of amlodipine in VSMC ATP2B1 KO mice as measured by the tail-cuff method $(\triangle \mathrm{SBP}-0.7 \pm 3.8$ vs. $-12.7 \pm 4.0 \mathrm{~mm} \mathrm{Hg} P<0.05)$. On the other hand, the difference was not seen when mice were administered candesartan ( $\triangle \mathrm{SBP}$ $-14.6 \pm 2.8$ vs. $-15.9 \pm 3.3 \mathrm{~mm} \mathrm{Hg}$, Figures $2 \mathrm{c}$ and d), which also has a long half-life. We also examined both short- and long-term effects of amlodipine by the radio telemetric method. Although there was no significant difference between the two groups on day 2 or 3 as an early phase, CCB demonstrated greater anti-hypertensive effects after 1-week and 2-week treatments in VSMC ATP2B1 KO mice (Figure 3a). By observing the changes in ambulatory blood pressure monitoring for $24 \mathrm{~h}$ at 1 week, the blood pressure-lowering effects of 

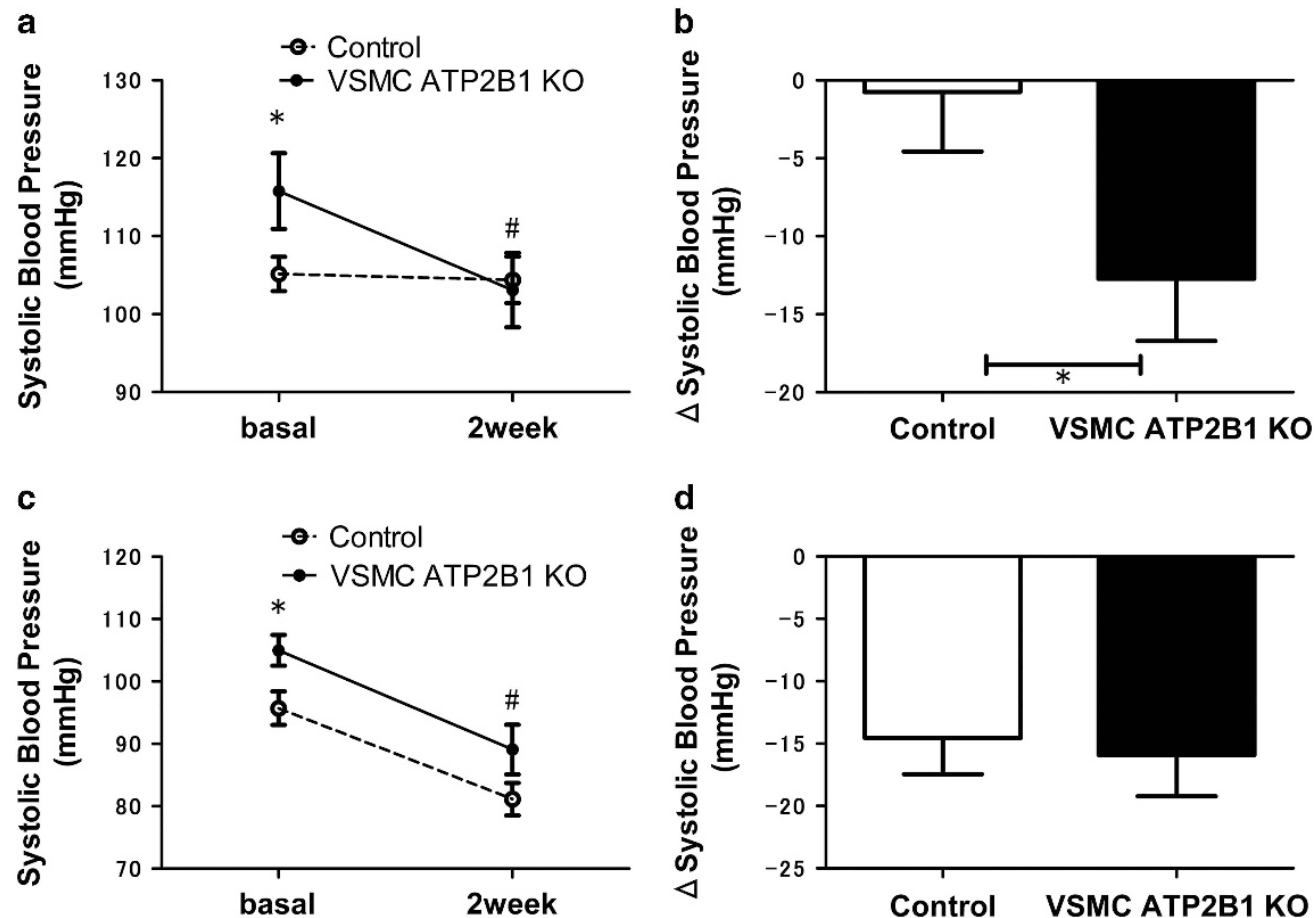

Figure 2 SBP shifts produced by long-term administration of amlodipine and candesartan measured by the tail-cuff method. (a) SBP and (b) Delta SBP from the baseline in mice administered amlodipine for 2 weeks $\left(5 \mathrm{mg} \mathrm{kg}^{-1}\right.$ per day, s.c., $n=9$ for each group). (c) SBP and (d) Delta SBP from the baseline in mice administered candesartan for 2 weeks $\left(0.5 \mathrm{mg} \mathrm{kg}^{-1}\right.$ per day, s.c., $n=7$ for each group). The data are means \pm s.e.m. of group. ${ }^{*} P<0.05 \mathrm{vs}$. the control group. ${ }^{\#} P<0.05$ vs. own baseline.

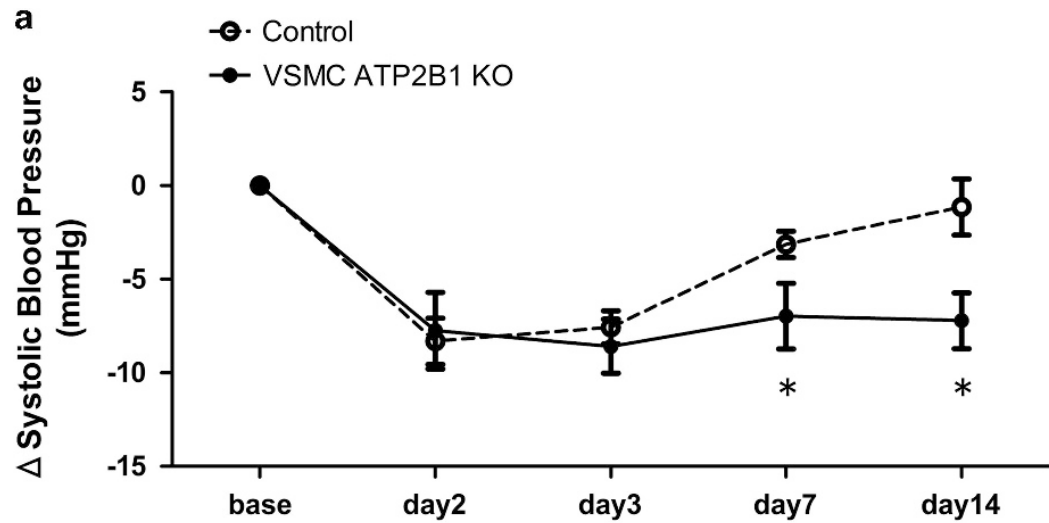

b

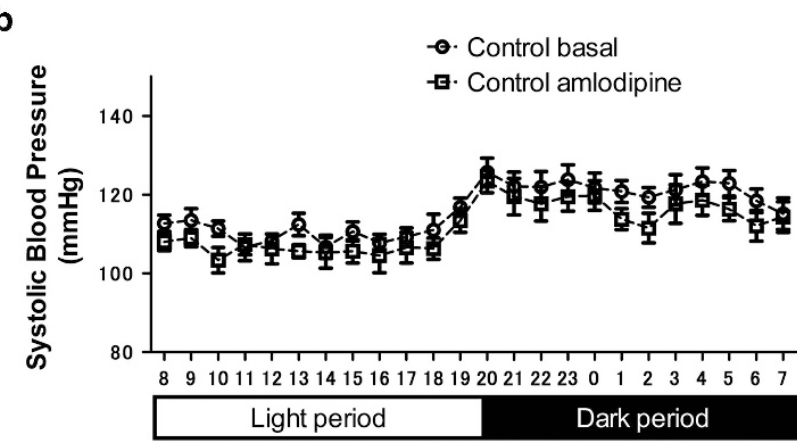

C

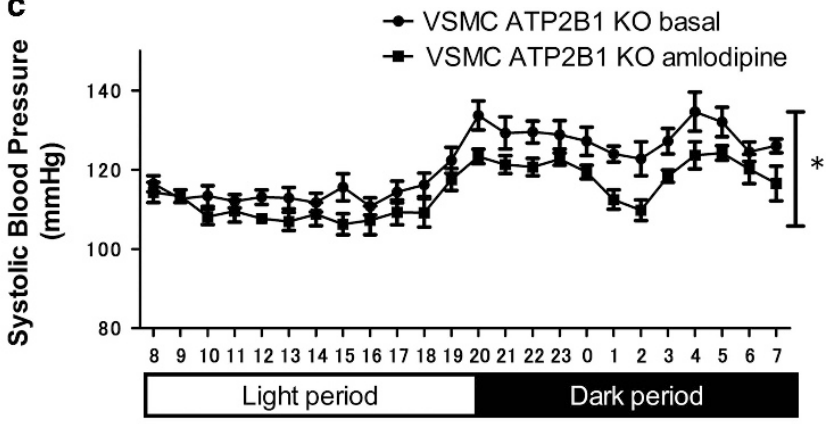

Figure $3 \mathrm{SBP}$ shifts produced by amlodipine administration on days 2, 3, 7, and 14 were examined by radio telemetric measurement. (a) Changes in delta SBP of mice treated with amlodipine $\left(5 \mathrm{mg} \mathrm{kg}^{-1}\right.$ per day, s.c., $\left.n=6-8\right)$. Circadian patterns of SBP of (b) Control and (c) VSMC ATP2B1 KO mice treated with amlodipine for 1 week, measured by the radio telemetric method. Basal SBPs were also measured $(n=6-8)$. 12-h light (8:00 AM to 20:00 PM)/dark (20:00 PM to 8:00 AM) cycle are shown. Values plotted are hourly means. Data are means \pm s.e.m. of group. ${ }^{*} P<0.05$ vs. the control group. 

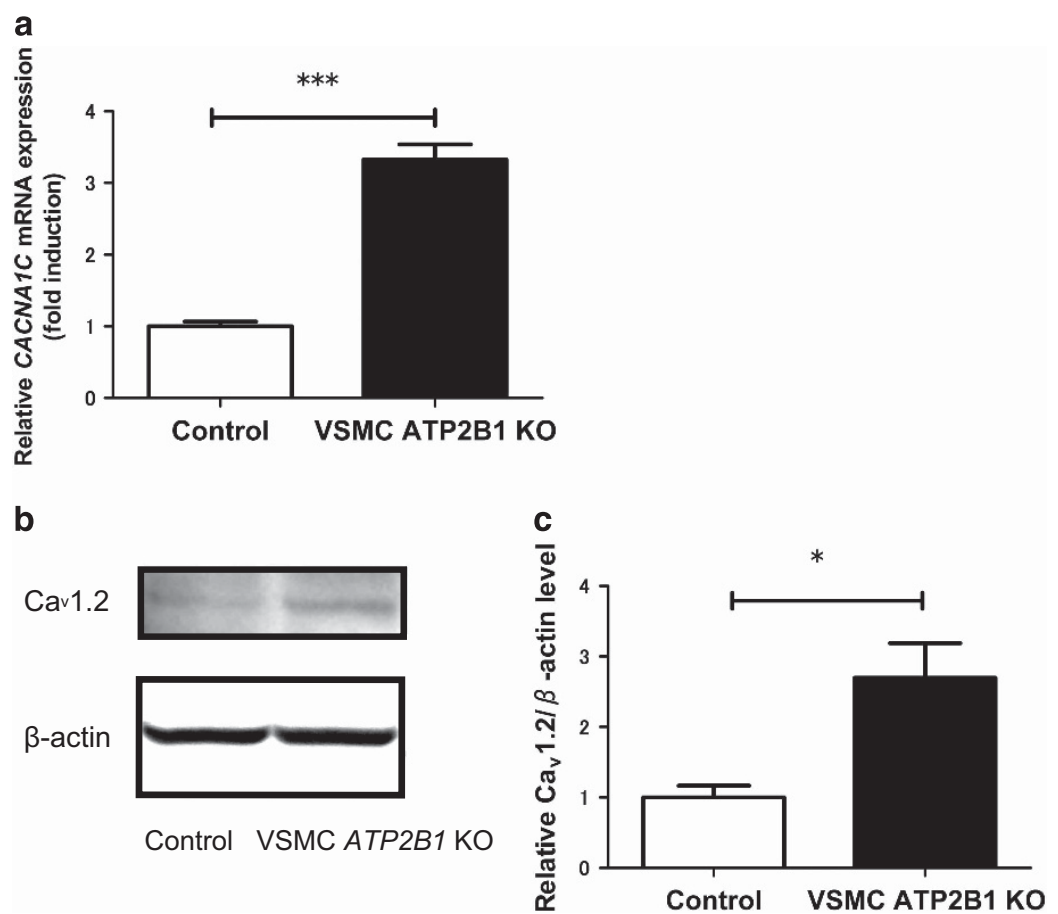

Figure 4 L-type calcium channel expression of VSMC ATP2B1 KO mice and control mice. (a) qRT-PCR measurement of CACNA1C mRNA expression in VSMCs ( $n=6$ for each group) (b and $\mathbf{c}$ ) representative Western blot and quantitative analysis of $\mathrm{Ca}_{\mathrm{v}} 1.2$ and $\beta$-actin protein expression in VSMCs. Values are calculated as $\mathrm{Ca}_{v} 1.2$ expression relative to $\beta$-actin expression ( $n=4$ for each group). Data are means \pm s.e.m. of each group. ${ }^{*} P<0.05$ vs. the control group. $* * * P<0.001$ vs. the control group.

amlodipine in VSMC ATP2B1 KO mice were especially seen in the dark period, and the effects were diminished throughout the day in control mice (Figures $3 \mathrm{~b}$ and $\mathrm{c}$ ).

\section{Expression of L-type calcium channels}

On the basis of the above results, we examined mRNA and protein expression of the $\alpha 1 \mathrm{C}$ subunit of the L-type calcium channel $\left(\mathrm{Ca}_{\mathrm{v}} 1.2\right)$ in VSMCs to investigate the mechanism of augmented effects of calcium channel blockers in $\mathrm{KO}$ mice. The expression of CACNA1C mRNA was upregulated (3.3-fold $P<0.001$, Figure 4 a) in VSMCs of $\mathrm{KO}$ mice. $\mathrm{Ca}_{\mathrm{v}} 1.2$ protein expression was also increased in KO VSMCs (2.7-fold $P<0.05$, Figures $4 \mathrm{~b}$ and $\mathrm{c}$ ).

\section{NO production of VSMC and urinary excretion of NO}

We examined nNOS protein expression in VSMCs and NOx production in urine to investigate whether KO mice had impaired NOS activity. Neural NOS protein expression was not different between VSMCs of control and $\mathrm{KO}$ mice (Figures $5 \mathrm{a}$ and b). Urinary excretion of NOx was not significantly different either (Figure 5c). Delta SBP was not changed significantly between control and knockout mice when L-NAME was administered (Figure 5d).

\section{DISCUSSION}

In the present study, we examined the efficacy of anti-hypertensive drugs to investigate the specificity of drug response and the mechanism of hypertensive phenomenon by deletion of the ATP2B1 gene in VSMCs. To the best of our knowledge, this is the first report to demonstrate the association between the ATP2B1 gene and CCB response. In response to a single administration of nicardipine, which is categorized as a dihydropyridine CCB with a short half-life, ${ }^{20}$ the blood pressure-lowering effects in $\mathrm{KO}$ mice were greater than in control mice. However, the anti-hypertensive effects of candesartan and prazosin were not different between $A T P 2 B 1$ knockout mice and the genetic control. Candesartan is categorized as an ARB, and no difference in the anti-hypertensive effect of an ARB administration suggests that high blood pressure was not caused by renin-angiotensin system stimulation. In the same way, prazosin, which primarily blocks vasoconstriction induced by $\alpha 1$-adrenergic receptors, ${ }^{21}$ decreased blood pressure equally between the two groups, indicating that elevated blood pressure in VSMC ATP2B1 KO mice may not be caused by sympathetic activation. These results suggest that the elevated intracellular calcium concentration of KO VSMCs contributes to high blood pressure and that blocking calcium entry through L-type calcium channels is effective, even with a single injection.

A single injection of amlodipine was thought to not sufficiently increase the blood concentration of the drug due to its long half-life, thereby causing no significant difference to be observed between the two groups. Therefore, we tried long-term administration. Two weeks of continuous amlodipine treatment significantly reduced blood pressure in VSMC ATP2B1 KO mice compared with control mice. The difference was seen after 1 week, but not at day 2 or 3 as an early phase measurement. One previous study demonstrated that repeated administration of amlodipine in humans resulted in steady state plasma drug concentration being reached after seven days. ${ }^{22}$ In comparison to the human data, our results indicated that amlodipine in VSMC ATP2B1 KO mice exhibited high blood pressure-lowering effects due to abnormalities in calcium handling after reaching a steady state. In other studies, mice treated with a high salt diet or angiotensin II received 5-6 mg kg-1 of amlodipine for several weeks, and amlodipine did not decrease blood pressure. ${ }^{23,24}$ Their results support our results that the systolic blood pressure of control mice treated with amlodipine for 2 weeks returned to baseline levels. Control mice may be fully compensated by other calcium transporters, whereas $\mathrm{KO}$ mice would be able to respond to CCBs permanently due to the lack of the 

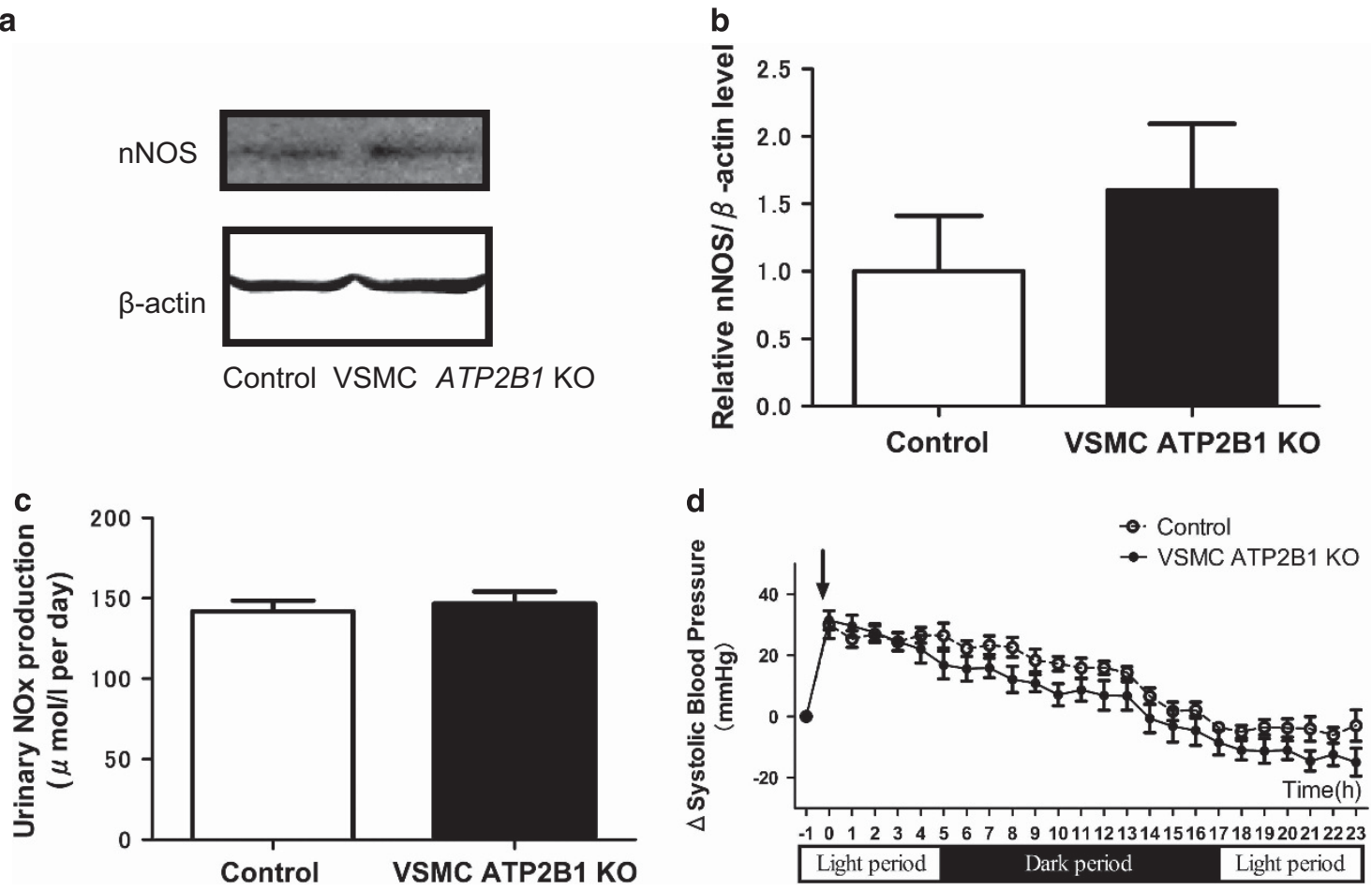

Figure 5 Nitric oxide synthase expression and NO production in VSMC ATP2B1 KO mice and control mice. (a, b) Representative Western blot and quantitative analysis of nNOS and $\beta$-actin protein expression in VSMCs. Values are calculated as nNOS expression relative to $\beta$-actin expression ( $n=4$ for each group). (c) NO production in urine evaluated by measuring NOx by the Griess method ( $n=6$ for each group). (d) Delta SBP in response to the administration of L-NAME (30 $\mathrm{mg} \mathrm{kg}^{-1}$, i.p., $n=8$ for each group). The arrow indicates the time of drug injection. A horizontal line shows the time after (or before) injection and each injection was at $\sim 3: 00$ PM. The data are means \pm s.e.m. of each group.

$A T P 2 B 1$ gene and subsequent abnormal expression of other calcium transporters (e.g., $\mathrm{NCX}^{7}$ and $\mathrm{Ca}_{\mathrm{v}} 1.2$ ). We also administered candesartan for 2 weeks because it has a long half-life, similar to amlodipine, and confirmed that the blood pressure-lowering effects were similar between the two groups.

Both $C A C N A 1 C$ gene and $\mathrm{Ca}_{\mathrm{v}} 1.2$ protein expression were significantly increased in KO VSMCs. $\mathrm{Ca}_{\mathrm{v}} 1.2$ channels are multi-subunit protein complexes composed of the three subunits $\alpha_{1}, \alpha_{2} \delta$, and $\beta,{ }^{25}$ and all calcium channel blockers bind to the $\alpha 1 \mathrm{C}$ subunit. ${ }^{26}$ There are considerable data that augmented $\mathrm{Ca}^{2+}$ influx through $\mathrm{Ca}_{\mathrm{v}} 1.2$ channels contributes to the augmented peripheral resistance and contractile responses of the vascular smooth muscle in hypertension. ${ }^{27}$ In previous studies, $\mathrm{Ca}_{\mathrm{v}} 1.2$ expression was reported to be upregulated in $\mathrm{SHR}^{28}$ and increased by high blood pressure ${ }^{29}$ or angiotensin II infusion ${ }^{30}$ in mice. These reports demonstrated that elevated $\mathrm{Ca}_{\mathrm{v}} 1.2$ protein expression means functional activation of the channel. As several studies reported that increased calcium entry through $\mathrm{Ca}_{\mathrm{v}} 1.2$ showed high response to CCBs in both human and animal models, ${ }^{29,31}$ upregulation of $\mathrm{Ca}_{\mathrm{v}} 1.2$ in VSMC $\mathrm{KO}$ mice may have promoted a high CCB response.

As reviewed by Harraz and Altier, ${ }^{32}$ the L-type calcium channel is activated by depolarization in response to action potentials or subthreshold stimuli. Pasic et al. ${ }^{29}$ suggested that high intravascular blood pressure-induced activation of $\mathrm{Ca}_{\mathrm{v}} 1.2$ protein involved membrane depolarization. Thus, the elevated intracellular calcium concentration due to lack of the ATP2B1 gene in VSMCs may promote an increase in membrane potentials and $\mathrm{Ca}_{\mathrm{v}} 1.2$ expression. Korb et al. ${ }^{33}$ reported that $\mathrm{Ca}_{\mathrm{v}} 1.2$ and PMCA4b bind promiscuously to several PDZ domains. Thus, the association between $\mathrm{Ca}_{\mathrm{v}} 1.2$ and PMCA1 may be recognized. Further study is needed to clarify the fundamental mechanism of the association between L-type calcium channels and ATP2B1.

On the other hand, systemic heterozygous ATP2B1-null mice exhibited impaired eNOS activity. ${ }^{10}$ Activity of NOS was unclear in VSMC ATP2B1 KO mice until we examined it in this study. It is well known that $\mathrm{NO}$ can influence contractility of peripheral blood vessels, and it is becoming more apparent that vascular NO production is not just mediated by eNOS but also via nNOS activity. ${ }^{34}$ Associations between nNOS and ATP2B4 are reported by several researchers. ${ }^{9,35}$ We speculated that nNOS was the most likely target if associations were seen between NOS and VSMC ATP2B1 KO mice because ATP2B4 mRNA expression was upregulated in those mice. ${ }^{7}$ However, nNOS protein expression was not changed in knockout mice compared with control mice. Furthermore, we administered L-NAME as a non-selective NOS inhibitor and checked urinary NOx excretion, which could be taken as an index of NO production, ${ }^{36}$ but no significant difference was seen in these experiments. These results indicated that NO production and all NOS isoform activity in VSMC $A T P 2 B 1 \mathrm{KO}$ mice were not impaired, and upregulation of $A T P 2 B 4$ in KO VSMCs did not influence the high blood pressure observed in these mice. Therefore, we considered that the increased intracellular calcium concentration was the main cause of the hypertensive phenomena in VSMC ATP2B1 KO mice.

There is a limitation in this study. We chose an L-type calcium channel blocker rather than T-type or N-type in the present study because extracellular $\mathrm{Ca}^{2+}$ influx is mainly mediated by the opening of L-type $\mathrm{Ca}^{2+}$ channels. ${ }^{37}$ Further studies are needed to investigate whether other calcium channels, such as T-type or N-type, contribute to the phenotype of increased intracellular calcium concentration in VSMCs of KO mice. 
In conclusion, we found that ATP2B1 VSMC-specific knockout mice had a high susceptibility to CCBs. The results mean that the effects of a lack of ATP2B1 on blood pressure are mainly due to increased intracellular calcium concentration and subsequent activation of L-type calcium channels. Our study indicates that low expression of the ATP2B1 gene in humans may induce higher efficacy of CCBs. It is of great importance that we investigate the response to CCBs in humans to promote tailored medicine. As the genomic data of candidate genes for hypertension are obtained in the future, ATP2B1 polymorphisms may be very useful tools for detecting CCB-sensitive patients among hypertensive people more easily and at lower cost.

\section{CONFLICT OF INTEREST}

$\mathrm{NH}$ received a research grant from Pfizer, and SU received lecture fees from Takeda, Behringer, Daiichi-Sankyo, MSD, Shionogi, and Kyowa Hakko Kirin, received manuscript fees from Sunmark publisher, and received scholarship donations from Takeda, Dainippon-Sumitomo, Pfizer, Asteras, Daiichi-Sankyo, Behringer, Novartis, Astorazeneka, Kowa, Shionogi, and MSD. KT received research grants from AstraZeneca, Ono Pharmaceutical, and Tsumura. NH and SU have been named as the inventors on a patent based on work on ATP2B1 SNPs and hypertension. The remaining authors declare no conflict of interest.

\section{ACKNOWLEDGEMENTS}

This work was supported by Grant-in -Aid for Scientific Research (JP25461249, JP16K09648) from the Ministry of Education, Culture, Sports, Science, and Technology, and the Japan Society for the promotion of Science, Japan; Grants for Research from Yokohama City University, Japan.

1 Little R, Cartwright EJ, Neyses L, Austin C. Plasma membrane calcium ATPases (PMCAs) as potential targets for the treatment of essential hypertension. Pharmacol Ther 2016; 159: 23-34.

2 Kohara K, Tabara Y, Nakura J, Imai Y, Ohkubo T, Hata A, Soma M, Nakayama T, Umemura S, Hirawa N, Ueshima H, Kita Y, Ogihara T, Katsuya T, Takahashi N, Tokunaga K, Miki T. Identification of hypertension-susceptibility genes and pathways by a systemic multiple candidate gene approach: the millennium genome project for hypertension. Hypertens Res 2008; 31: 203-212.

3 Levy D, Ehret GB, Rice K, Verwoert GC, Launer LJ, Dehghan A, Glazer NL, Morrison AC, Johnson AD, Aspelund T, Aulchenko Y, Lumley T, Kottgen A, Vasan RS, Rivadeneira F, Eiriksdottir G, Guo X, Arking DE, Mitchell GF, Mattace-Raso FU, Smith AV, Taylor K, Scharpf RB, Hwang SJ, Sijbrands EJ, Bis J, Harris TB, Ganesh SK, O'Donnell CJ, Hofman A, Rotter JI, Coresh J, Benjamin EJ, Uitterlinden AG, Heiss G, Fox CS, Witteman JC, Boerwinkle E, Wang TJ, Gudnason V, Larson MG, Chakravarti A, Psaty BM, van Duijn CM. Genome-wide association study of blood pressure and hypertension. Nat Genet 2009; 41: 677-687.

4 Cho YS, Go MJ, Kim YJ, Heo JY, Oh JH, Ban HJ, Yoon D, Lee MH, Kim DJ, Park M, Cha SH, Kim JW, Han BG, Min H, Ahn Y, Park MS, Han HR, Jang HY, Cho EY, Lee JE, Cho NH, Shin C, Park T, Park JW, Lee JK, Cardon L, Clarke G, McCarthy MI, Lee JY, Lee JK, Oh B, Kim HL. A large-scale genome-wide association study of Asian populations uncovers genetic factors influencing eight quantitative traits. Nat Genet 2009; 41: 527-534.

5 International Consortium for Blood Pressure Genome-Wide Association S, Ehret GB, Munroe PB, Rice KM, Bochud M, Johnson AD, Chasman DI, Smith AV, Tobin MD, Verwoert GC, Hwang SJ, Pihur V, Vollenweider P, O'Reilly PF, Amin N, Bragg-Gresham JL, Teumer A, Glazer NL, Launer L, Zhao JH, Aulchenko Y, Heath S, Sober S, Parsa A, Luan J, Arora P, Dehghan A, Zhang F, Lucas G, Hicks AA, Jackson AU, Peden JF, Tanaka T, Wild SH, Rudan I, IgI W, Milaneschi Y, Parker AN, Fava C, Chambers JC, Fox ER, Kumari M, Go MJ, van der Harst P, Kao WH, Sjogren M, Vinay DG, Alexander M, Tabara Y, Shaw-Hawkins S, Whincup PH, Liu Y, Shi G, Kuusisto J, Tayo B, Seielstad M, Sim X, Nguyen KD, Lehtimaki T, Matullo G, Wu Y, Gaunt TR, Onland-Moret NC, Cooper MN, Platou CG, Org E, Hardy R, Dahgam S, Palmen J, Vitart V, Braund PS, Kuznetsova T, Uiterwaal CS, Adeyemo A, Palmas W, Campbell H, Ludwig B, Tomaszewski M, Tzoulaki I, Palmer ND, consortium CA, Consortium CK, KidneyGen C, EchoGen C, consortium C-H, Aspelund T, Garcia M, Chang YP, O'Connell JR, Steinle NI, Grobbee DE, Arking DE, Kardia SL, Morrison AC, Hernandez D, Najjar S, McArdle WL, Hadley D, Brown MJ, Connell JM, Hingorani AD, Day IN, Lawlor DA, Beilby JP, Lawrence RW, Clarke R, Hopewell JC, Ongen H, Dreisbach AW, Li Y, Young JH, Bis JC, Kahonen M, Viikari J, Adair LS, Lee NR, Chen MH, Olden M, Pattaro C, Bolton JA, Kottgen A, Bergmann S, Mooser V, Chaturvedi N, Frayling TM, Islam M, Jafar TH, Erdmann J, Kulkarni SR, Bornstein SR, Grassler J, Groop L, Voight BF, Kettunen J, Howard P, Taylor A, Guarrera S, Ricceri F,
Emilsson V, Plump A, Barroso I, Khaw KT, Weder AB, Hunt SC, Sun YV, Bergman RN, Collins FS, Bonnycastle LL, Scott LJ, Stringham HM, Peltonen L, Perola M, Vartiainen E, Brand SM, Staessen JA, Wang TJ, Burton PR, Soler Artigas M, Dong Y, Snieder H, Wang X, Zhu H, Lohman KK, Rudock ME, Heckbert SR, Smith NL, Wiggins KL, Doumatey A, Shriner D, Veldre G, Viigimaa M, Kinra S, Prabhakaran D, Tripathy V, Langefeld CD, Rosengren A, Thelle DS, Corsi AM, Singleton A, Forrester T, Hilton G, McKenzie CA, Salako T, Iwai N, Kita Y, Ogihara T, Ohkubo T, Okamura T, Ueshima H, Umemura S, Eyheramendy S, Meitinger T, Wichmann HE, Cho YS, Kim HL, Lee JY, Scott J, Sehmi JS, Zhang W, Hedblad B, Nilsson P, Smith GD, Wong A, Narisu N, Stancakova A, Raffel LJ, Yao J, Kathiresan S, O'Donnell CJ, Schwartz SM, Ikram MA, Longstreth WT Jr, Mosley TH, Seshadri S, Shrine NR, Wain LV, Morken MA, Swift AJ, Laitinen J, Prokopenko I, Zitting P, Cooper JA, Humphries SE, Danesh J, Rasheed A, Goel A, Hamsten A, Watkins H, Bakker SJ, van Gilst WH, Janipalli CS, Mani KR, Yajnik CS, Hofman A, Mattace-Raso FU, Oostra BA, Demirkan A, Isaacs A, Rivadeneira F, Lakatta EG, Orru M, Scuteri A, Ala-Korpela M, Kangas AJ, Lyytikainen LP, Soininen P, Tukiainen T, Wurtz P, Ong RT, Dorr M, Kroemer HK, Volker U, Volzke H, Galan P, Hercberg S, Lathrop M, Zelenika D, Deloukas $P$, Mangino M, Spector TD, Zhai G, Meschia JF, Nalls MA, Sharma P, Terzic J, Kumar MV, Denniff M, Zukowska-Szczechowska E, Wagenknecht LE, Fowkes FG, Charchar FJ, Schwarz PE, Hayward C, Guo X, Rotimi C, Bots ML, Brand E, Samani NJ, Polasek O, Talmud PJ, Nyberg F, Kuh D, Laan M, Hveem K, Palmer LJ, van der Schouw YT, Casas JP, Mohlke KL, Vineis P, Raitakari O, Ganesh SK, Wong TY, Tai ES, Cooper RS, Laakso M, Rao DC, Harris TB, Morris RW, Dominiczak AF, Kivimaki M, Marmot MG, Miki T, Saleheen D, Chandak GR, Coresh J, Navis G, Salomaa V, Han BG, Zhu X, Kooner JS, Melander O, Ridker PM, Bandinelli S, Gyllensten UB, Wright AF, Wilson JF, Ferrucci L, Farrall M, Tuomilehto J, Pramstaller PP, Elosua R, Soranzo N, Sijbrands EJ, Altshuler D, Loos RJ, Shuldiner AR, Gieger C, Meneton P, Uitterlinden AG, Wareham NJ, Gudnason V, Rotter JI, Rettig R, Uda M, Strachan DP, Witteman JC, Hartikainen AL, Beckmann JS, Boerwinkle E, Vasan RS, Boehnke M, Larson MG, Jarvelin MR, Psaty BM, Abecasis GR, Chakravarti A, Elliott $P$, van Duijn CM, Newton-Cheh C, Levy D, Caulfield MJ, Johnson T. Genetic variants in novel pathways influence blood pressure and cardiovascular disease risk. Nature 2011; 478: 103-109.

6 Tabara Y, Kohara K, Kita Y, Hirawa N, Katsuya T, Ohkubo T, Hiura Y, Tajima A, Morisaki T, Miyata T, Nakayama T, Takashima N, Nakura J, Kawamoto R, Takahashi N, Hata A, Soma M, Imai Y, Kokubo Y, Okamura T, Tomoike H, Iwai N, Ogihara T, Inoue I, Tokunaga K, Johnson T, Caulfield M, Munroe P, Global Blood Pressure Genetics C, Umemura S, Ueshima H, Miki T. Common variants in the ATP2B1 gene are associated with susceptibility to hypertension: the Japanese Millennium Genome Project. Hypertension 2010; 56: 973-980.

7 Kobayashi Y, Hirawa N, Tabara Y, Muraoka H, Fujita M, Miyazaki N, Fujiwara A, Ichikawa Y, Yamamoto Y, Ichihara N, Saka S, Wakui H, Yoshida S, Yatsu K, Toya Y, Yasuda G, Kohara K, Kita Y, Takei K, Goshima Y, Ishikawa Y, Ueshima H, Miki T, Umemura S. Mice lacking hypertension candidate gene ATP2B1 in vascular smooth muscle cells show significant blood pressure elevation. Hypertension 2012; 59: 854-860.

8 Hirawa N, Fujiwara A, Umemura S. ATP2B1 and blood pressure: from associations to pathophysiology. Curr Opin Nephrol Hypertens 2013; 22: 177-184.

9 Gros R, Afroze T, You XM, Kabir G, Van Wert R, Kalair W, Hoque AE, Mungrue IN, Husain M. Plasma membrane calcium ATPase overexpression in arterial smooth muscle increases vasomotor responsiveness and blood pressure. Circ Res 2003; 93: 614-621.

10 Fujiwara A, Hirawa N, Fujita M, Kobayashi Y, Okuyama Y, Yatsu K, Katsumata M, Yamamoto Y, Ichihara N, Saka S, Toya Y, Yasuda G, Goshima Y, Tabara Y, Miki T, Ueshima $\mathrm{H}$, Ishikawa $\mathrm{Y}$, Umemura $\mathrm{S}$. Impaired nitric oxide production and increased blood pressure in systemic heterozygous ATP2B1 null mice. J Hypertens 2014; 32: 1415-1423, discussion 1423

11 Shimamoto K, Kimoto M, Matsuda Y, Asano K, Kajikawa M. Long-term safety and efficacy of high-dose controlled-release nifedipine ( $80 \mathrm{mg}$ per day) in Japanese patients with essential hypertension. Hypertens Res 2015; 38: 695-700.

12 Holtwick R, Gotthardt M, Skryabin B, Steinmetz M, Potthast R, Zetsche B, Hammer RE, Herz J, Kuhn M. Smooth muscle-selective deletion of guanylyl cyclase-A prevents the acute but not chronic effects of ANP on blood pressure. Proc Natl Acad Sci USA 2002; 99: 7142-7147.

13 Yamazaki D, Tabara Y, Kita S, Hanada H, Komazaki S, Naitou D, Mishima A, Nishi M, Yamamura H, Yamamoto S, Kakizawa S, Miyachi H, Yamamoto S, Miyata T, Kawano Y, Kamide K, Ogihara T, Hata A, Umemura S, Soma M, Takahashi N, Imaizumi Y, Miki T, Iwamoto T, Takeshima H. TRIC-A channels in vascular smooth muscle contribute to blood pressure maintenance. Cell Metab 2011; 14: 231-241.

14 Pelat M, Dessy C, Massion P, Desager JP, Feron O, Balligand JL. Rosuvastatin decreases caveolin-1 and improves nitric oxide-dependent heart rate and blood pressure variability in apolipoprotein E-l- mice in vivo. Circulation 2003; 107: 2480-2486.

15 Doran DE, Weiss D, Zhang Y, Griendling KK, Taylor WR. Differential effects of AT1 receptor and $\mathrm{Ca}_{2}{ }^{+}$channel blockade on atherosclerosis, inflammatory gene expression, and production of reactive oxygen species. Atherosclerosis 2007; 195: 39-47.

16 Zhang C, Yasuno S, Kuwahara K, Zankov DP, Kobori A, Makiyama T, Horie M. Blockade of angiotensin II type 1 receptor improves the arrhythmia morbidity in mice with left ventricular hypertrophy. Circ J 2006; 70: 335-341.

17 Yayama K, Miyagi R, Sugiyama K, Sugaya T, Fukamizu A, Okamoto H. Angiotensin II regulates liver regeneration via type 1 receptor following partial hepatectomy in mice. Biol Pharm Bull 2008; 31: 1356-1361

18 Kobayashi M, Inoue K, Warabi E, Minami T, Kodama T. A simple method of isolating mouse aortic endothelial cells. J Atheroscler Thromb 2005; 12: 138-142. 
19 Leenen FH, Fourney A, Notman G, Tanner J. Persistence of anti-hypertensive effect after 'missed doses' of calcium antagonist with long (amlodipine) vs. short (diltiazem) elimination half-life. Br J Clin Pharmacol 1996; 41: 83-88.

20 Curran MP, Robinson DM, Keating GM. Intravenous nicardipine: its use in the shortterm treatment of hypertension and various other indications. Drugs 2006; 66 1755-1782.

21 Duka I, Gavras I, Johns C, Handy DE, Gavras H. Role of the postsynaptic alpha(2)adrenergic receptor subtypes in catecholamine-induced vasoconstriction. Gen Pharmacol 2000; 34: 101-106.

22 Faulkner JK, McGibney D, Chasseaud LF, Perry JL, Taylor IW. The pharmacokinetics of amlodipine in healthy volunteers after single intravenous and oral doses and after 14 repeated oral doses given once daily. Br J Clin Pharmacol 1986; 22: 21-25.

23 Chen X, Rateri DL, Howatt DA, Balakrishnan A, Moorleghen JJ, Morris AJ, Charnigo $R$, Cassis LA, Daugherty $A$. Amlodipine reduces Angll-induced aortic aneurysms and atherosclerosis in hypercholesterolemic mice. PLOS ONE 2013; 8: e81743.

24 Devarajan S, Yahiro E, Uehara Y, Habe S, Nishiyama A, Miura S, Saku K, Urata H. Depressor effect of chymase inhibitor in mice with high salt-induced moderate hypertension. Am J Physiol Heart Circ Physiol 2015; 309: H1987-H1996.

25 Hofmann F, Flockerzi V, Kahl S, Wegener JW. L-type CaV1.2 calcium channels: from in vitro findings to in vivo function. Physiol Rev 2014; 94: 303-326.

26 Abernethy DR, Schwartz JB. Calcium-antagonist drugs. N Engl J Med 1999; 341 1447-1457.

27 Chen Y, Zhang H, Zhang Y, Lu N, Zhang L, Shi L. Exercise intensity-dependent reverse and adverse remodeling of voltage-gated $\mathrm{Ca}^{(2+)}$ channels in mesenteric arteries from spontaneously hypertensive rats. Hypertens Res 2015; 38: 656-665.

28 Pratt PF, Bonnet S, Ludwig LM, Bonnet P, Rusch NJ. Upregulation of L-type $\mathrm{Ca}^{2+}$ channels in mesenteric and skeletal arteries of SHR. Hypertension 2002; 40: 214-219.

29 Pesic A, Madden JA, Pesic M, Rusch NJ. High blood pressure upregulates arterial L-type $\mathrm{Ca}^{2+}$ channels: is membrane depolarization the signal? Circ Res 2004; 94 e97-104.

30 Wang WZ, Pang L, Palade P. Angiotensin II causes endothelial-dependent increase in expression of $\mathrm{Ca}(\mathrm{V}) 1.2$ protein in cultured arteries. Eur J Pharmacol 2008; 599: 117-120.
31 Hutri-Kahonen N, Kahonen M, Wu X, Sand J, Nordback I, Taurio J, Porsti I. Control of vascular tone in isolated mesenteric arterial segments from hypertensive patients. $\mathrm{Br} \mathrm{J}$ Pharmacol 1999; 127: 1735-1743.

32 Harraz OF, Altier C. STIM1-mediated bidirectional regulation of $\mathrm{Ca}^{(2+)}$ entry through voltage-gated calcium channels (VGCC) and calcium-release activated channels (CRAC). Front Cell Neurosci 2014; 8: 43.

33 Korb D, Tng PY, Milenkovic VM, Reichhart N, Strauss O, Ritter O, Fischer T, Benz PM, Schuh K. Identification of PDZ domain containing proteins interacting with 1.2 and PMCA4b. ISRN Cell Biol 2013; 2013: 1-16.

34 Zhao Y, Vanhoutte PM, Leung SW. Vascular nitric oxide: Beyond eNOS. J Pharmacol Sci 2015; 129: 83-94.

35 Schuh K, Quaschning T, Knauer S, Hu K, Kocak S, Roethlein N, Neyses L. Regulation of vascular tone in animals overexpressing the sarcolemmal calcium pump. J Biol Chem 2003; 278: 41246-41252.

36 Bank N, Aynedjian HS. Role of EDRF (nitric oxide) in diabetic renal hyperfiltration. Kidney Int 1993; 43: 1306-1312.

37 Brozovich FV, Nicholson CJ, Degen CV, Gao YZ, Aggarwal M, Morgan KG. Mechanisms of vascular smooth muscle contraction and the basis for pharmacologic treatment of smooth muscle disorders. Pharmacol Rev 2016; 68: 476-532.

cc)(1) $\Theta$ This work is licensed under a Creative Commons Attribution-NonCommercial-NoDerivs 4.0 International License. The images or other third party material in this article are included in the article's Creative Commons license, unless indicated otherwise in the credit line; if the material is not included under the Creative Commons license, users will need to obtain permission from the license holder to reproduce the material. To view a copy of this license, visit http://creativecommons.org/licenses/bync-nd/4.0/

(C) The Author(s) 2018

Supplementary Information accompanies the paper on Hypertension Research website (http://www.nature.com/hr) 